\title{
Play as a care strategy for children with cancer
}

\author{
O lúdico como estratégia no cuidado à criança com câncer \\ Lo lúdico como estrategia en cuidado de niños con cáncer
}

\section{Kálya Yasmine Nunes de Lima ${ }^{a}$ Viviane Euzébia Pereira Santos ${ }^{b}$}

\section{ABSTRACT}

Objective: To understand the influence of play in the care process as perceived by children with cancer.

Method: A descriptive, exploratory and qualitative study conducted in a children's cancer unit in Natal, Rio Grande do Norte, Brazil. Data were collected between October 2013 and January 2014 by means of photographic records and semi-structured interviews with eight children, and content analysis with emphasis on two categories: Auxiliary instruments during play; and The influence of play in the process of care.

Results: Recreational activities involve watching television, using computers, games and toys, drawing, the playroom and the clown, which provide fun, feelings of joy, distraction and interaction with other people.

Conclusion: There are several activities at the hospital that are considered play-related and, for the children, they all benefit their care process.

Keywords: Play therapy. Oncology nursing. Child, hospitalized.

\section{RESUMO}

Objetivos: Compreender a influência do lúdico para o processo de cuidar, na percepção de crianças com câncer.

Método: Estudo qualitativo, exploratório descritivo, realizado em um setor de oncopediatria em Natal, Rio Grande do Norte, Brasil. Os dados foram coletados entre os meses de outubro de 2013 e janeiro de 2014, por meio de registros fotográficos e entrevista semiestruturada, com oito crianças, e analisados conforme a Análise de Conteúdo, destacando-se duas categorias de discussão: Os instrumentos auxiliares na ludicidade; e A influência do lúdico no processo de cuidar.

Resultados: As atividades lúdicas envolvem o assistir à televisão, o uso de computadores, os jogos e os brinquedos, a realização de desenhos, a brinquedoteca e o palhaço, os quais proporcionam diversão, sentimentos de alegria, distração e interação com outras pessoas. Conclusão: Existem diversas atividades, no hospital, entendidas como lúdicas, todas as quais, para a criança, proporcionam benefícios para o seu processo de cuidar.

Palavras-chave: Ludoterapia. Enfermagem oncológica. Criança hospitalizada.

\section{RESUMEN}

Objetivo: Comprender la influencia de lo lúdico en el proceso de atención, en la percepción de los niños con cáncer.

Método: Estudio cualitativo, exploratorio descriptivo, realizado en un sector de oncología pediátrica en Natal, Rio Grande do Norte, Brasil. Los datos fueron recogidos entre los meses de octubre de 2013 y enero de 2014, a través de los registros fotográficos y entrevistas semiestructuradas con ocho hijos, y analizados según el análisis de contenido, destacando dos categorías de discusión: Los instrumentos auxiliares en la alegría; La influencia de lo lúdico en el proceso de atención.

Resultados: Las actividades recreativas implican ver televisión, usar computadoras, juegos y juguetes, la realización de dibujos y el payaso, que proporcionan diversión, sentimientos de alegría, distracción y la interacción con los demás.

Conclusión: Hay varias actividades, en el hospital, entendido como lúdico y que, para el niño, todos proporcionan beneficios para su proceso de atención.

Palabras clave: Ludoterapia. Enfermería oncológica. Niño hospitalizado.
D0l: http://dx.doi.org/10.1590/1983-

1447.2015.02.51514

\footnotetext{
a Master of Nursing of the Post-Graduate Nursing Programme from the Universidade Federal do Rio Grande do Norte, Natal, Rio Grande do Norte, Brazil.

${ }^{b}$ Doctor of Nursing Practice. Adjunct Professor of the Department of Nursing and the Post-Graduate Nursing Programme, and head of the research group at the laboratory of care, safety and health technologies and nursing investigations of the Universidade Federal do Rio Grande do Norte, Natal, Rio Grande do Norte, Brazil.
} 


\section{口INTRODUCTION}

Childhood is a period of life in which the main occupation of children is play. This activity is critical to maintain the physical and mental health of children. Play can include objects and occur individually or in a group ${ }^{(1)}$.

Play, which is based on the intention of having fun and psychosocial development, provides new sensations, creates and recreates everyday life situations and helps children discover the world. It also supports an encounter with reality and transforms and adapts reality to the wishes of children ${ }^{(2)}$

However, some situations can hinder play, and one such situation is hospitalization. Children's cancer is a disease that requires multiple hospital admissions. In this process, children are forced to leave their homes and the company of their loved ones to adapt to the hospital environment and everything it involves.

The illness and hospitalization of children, in this sense, represents a rupture from their everyday lives. These children find themselves in a restricted location, where hospital routines and the environment itself reduce the range of activities they are used to practicing, which can disrupt their natural development ${ }^{(2)}$.

Furthermore, given the health condition of these children, they are instructed to avoid certain activities and contact with other patients, which reduces their interaction with people and sometimes causes fear in relation to the illness and treatment. Thus, hospitalization is perceived as an aggression against their world of play and magic and can trigger negative feelings such as anger, sadness and depression ${ }^{(2)}$.

Consequently, play becomes a strategy that can minimize the discomforts caused by hospitalization and assist in the fight against the disease. It can also facilitate nursing interventions and must be incorporated as an interface of care for children with cancer ${ }^{(3)}$.

Nurses should consider play as the most appropriate way to develop empathy and as a channel to understand the world from the viewpoint of children, which subsequently encourages bonding ${ }^{(4)}$.

In addition to professionals with technical skills and knowledge, care for hospitalized children with cancer requires health workers who show empathy and involvement with their patients. These qualities enable the identification of real physical, psychological and social demands of these children, and help to build a care plan that is compatible with their individuality.

This perception of the importance of play during hospitalization for the development of children and the humanization of hospital relations led to the following question:
Which activities are considered as play by hospitalized children with cancer? What is the influence of these activities in the process of care from the perspective of children? The aim of this study was to understand how children with cancer perceive the influence of play on the process of care.

\section{METHODOLOGY}

This descriptive, exploratory and qualitative study is part of the results of a dissertation titled "Processo de cuidar de crianças hospitalizadas com câncer"(5), conducted in a children's cancer unit in the municipality of Natal, Rio Grande do Norte, Brazil.

To assist children with cancer, the hospital provides three nursing units, one of which has three beds and two with two beds, in addition to the isolation and out-patient sectors. The unit is decorated with children's paintings and each room has a television, air conditioning and cabinets. For fun and entertainment, the institution offers a playroom with specific opening hours. The nursing team comprises five nursing technicians in the morning shift, five in the afternoon and only two at night. During the shifts, there is always a nurse who provides care in the out-patient and admissions sector.

Research participants were children between the ages of six and twelve who were hospitalized for cancer treatment. Inclusion criteria was hospitalization for cancer treatment and favourable physical conditions for data collection. Exclusion criteria was the inability to handle the imaging instrument and children that were not physically or emotionally able to participate in the study. Considering the data saturation criteria, the study sample comprised eight children.

Data were collected between October 2013 and January 2014. The authors contacted the sector nurse in search of children with a confirmed diagnosis of cancer. The person responsible for each child and the child were approached in the nursing unit, notified of the study and asked to participate in the study by signing the informed consent statement. Then, each child was given a photographic camera and asked to register the moments he or she considered as being part of the care provided by the hospital. The registered photographs were projected on a computer while the researchers initiated the structured interviews with the following three guiding questions: Can you explain what is in the photograph? Why did you choose this photograph? Where is the care portrayed in this photograph?

The period for registering images corresponded to one shift, during which the researcher remained in the study sector. After excluding repeated and low quality images, all 
the remaining photographs were used in the interview. Although the parents or guardians of the children were present during data collection, they did not participate in the method procedures. All the collected data refer only to the experiences and perceptions of the children.

A field journal was used to record observations that could be relevant to data analysis. To better record and subsequently transcribe the information, all interviews were taped with the permission of the guardian of each child.

Data were analyzed and interpreted based on thematic content analysis. The pre-analysis stage consisted of organizing the material collected during the interviews. In the exploration phase, the selected documents were analyzed and the study subjects were coded and selected. During the results treatment stage, the collected data were interpreted to establish relationships between the study object and its broader context(6).

The research was approved by the Ethics Committee of the Liga Norte Riograndense contra o Câncer according to decision 329.015 and CAAE 16097613.9.0000.5293, in accordance with Resolution 466, of December 12, 2012, of the National Health Council. The guardians of the children signed the informed consent statement. To ensure the anonymity of research participants, they were identified using the names of children's cartoon characters.

\section{RESULTS AND DISCUSSION}

\section{Introducing the children}

Spider-man, a ten-year-old boy diagnosed with leukaemia seven years ago, with relapse and currently undergoing maintenance treatment. He was admitted at the institution two days previously for chemotherapy, accompanied by his mother. He was approached while watching television in his room.

Draculaura, a six-year-old girl diagnosed a year and ten months ago with leukaemia, undergoing maintenance treatment. She had been hospitalized the day before, accompanied by her mother, when she was approached to participate in the study.

Minnie, an eleven-year-old girl, accompanied by her father. She was diagnosed with leukaemia five years ago, and was undergoing consolidation therapy. She had been admitted one day previously, and was drawing on her bed when she was approached.

Thor, an eight-year-old boy, accompanied by his mother and diagnosed with leukaemia three years ago, undergoing maintenance treatment. He had been admitted at the institution for postoperative care for appendectomy two days previously and was watching television when invited to participate in this study.

Mickey, a nine-year-old boy diagnosed with leukaemia two years and three months ago, undergoing maintenance treatment. He was admitted one day previously, in the company of his mother, and was using a computer to play on his bed when approached to participate in the study.

Julio, a six-year-old boy diagnosed with leukaemia three years ago, undergoing maintenance treatment and admitted two days previously. He was accompanied by his mother and had a box of toys on his bed when approached.

Woody Woodpecker, a six-year-old boy diagnosed with leukaemia five years ago, with relapse and undergoing maintenance treatment. He had been admitted two days previously and was accompanied by his mother. He was watching television in the nursing unit when approached.

Ben 10, a twelve-year-old boy diagnosed with medulloblastoma six years ago. He was admitted one day previously, in the company of his mother. He was watching television in the nursing unit when invited to participate in the study.

The interviews and data analysis led to two categories of discussion: Auxiliary instruments during play; and The influence of play in the process of care.

\section{Auxiliary instruments during play}

Most children perceive hospitals as places that restrict play, either by keeping them away from their families and routine or in relation to their physical condition that requires the use of medication, catheters and other limitations that can impair movement and prevent them from walking freely in the nursing unit. Play is therefore considered a way to reduce the discomforts of hospitalization.

The main play strategies used by nurses in children's care, according to literature, are the clown theater, puppets, games and the therapeutic doll(8), which reveals a range of options to bring play into the hospital.

In this study, the children stated the following in relation to play:

Ali is a patient, he has a laptop. He's playing with it [...], I play on the computer. (Minnie)

Television... because it's boring without a television... and I can watch shows and other things. It's good. [...] there's the computer. (Mickey)

Television [...] to watch cartoons, DVDs. (Woody Woodpecker) 
It was observed that the children used the electronic devices supplied at the hospital as a form of entertainment. The most important individual device was the computer, which was not provided at the institution and could be brought from home for their entertainment.

In time, play has changed due to the influence of advanced technology and the consequent growth of industrialized toys ${ }^{(9)}$. This has led children to seek electronic devices as a form of fun. These devices might also have been mentioned because they are easily handled and the children do not need to leave their beds to use them.

Children that are hospitalized for cancer treatment are usually using medication and/or instruments that hinder movement. They also suffer from a certain fatigue when performing other activities. This may lead them to prefer activities that can be easily performed in their own beds.

The use of technological tools in health care, such as computers, can be considered an excellent form of informative play that keeps children busy and distracts them from their illness and its treatment. The games and software provided with these devices also promote health education and help them maintain the bond with family members and friends outside the hospital environment ${ }^{(10)}$. It is believed that access to the Internet and the use of specific programmes should be further explored by nurses and multi-professional teams as an additional care strategy for children with cancer.

Other instruments mentioned as auxiliaries in the care process were games, toys and drawing:

Play ... games ... because it's cool. (Julio)

\section{There are the toys, too. I like drawing. (Minnie)}

Playing independently or in a group is a strategy used by children and health care professionals. In this type of activity, health workers encourage the children to play freely when using games, toys, modelling clay, magazine cut outs and puppets ${ }^{(11)}$, thus creating a purely recreational activity that does not require the presence of these professionals.

In the referred institution, games, pens and paper were sometimes offered to the children. Withal, the game mentioned by Julio belonged to him and it was brought from his home to the hospital.

Play has been valued and studied in several studies in the area of health care. In 2005, law 11.104 was established for this purpose. Article 1 of this law stipulates that hospitals offering paediatric care must have playrooms with toys and educational games designed to encourage children and their companions to play ${ }^{(12)}$.
This instrument was mentioned by the children as follows:

There is that little room, too, with toys. There are lots of things there. (Minnie)

There is a playroom, too, the books, the teacher. (Mickey)

Pencil, [coloured pen] set... I like to draw, paint... it's nice. There is a games room too, there's a lot of stuff ... you can play, paint, do a bunch of stuff there ... [...] the little pens ... it's good to write, to draw. (Woody Woodpecker)

As stated in the study, the hospital has a playroom where a wide range of activities can be carried out, including drawing and playing with toys.

It is worth noting that the time spent playing in these areas is also an opportunity for social interaction ${ }^{(13)}$ because the room is usually used by more than one child at the same time, as shown during this study.

The interviewed children also seemed anxious about the opportunity they would have to use the playroom. When this playroom was mentioned as a form of care, Woody Woodpecker and Mickey turned to the nurse of the unit to ask her when the room would be open and if they could use it.

Another possibility when working with play during hospitalization is the presence of clowns:

\section{The clown [...] he comes to play with people. (Spider-Man)}

The clown mentioned was represented by a volunteer at the institution who prepared activities with the children once or twice a week, during a shift. He visited all the rooms and entertained the children by making balloon animals and encouraging them to participate in games.

This type of activity can be carried out by professionals at the institution or by volunteers. They can create a character and dress up accordingly. Normally, they use clown noses, coloured stethoscopes and suitcases, and interact with children through music, storytelling, magic and even dramatization ${ }^{(14)}$, as witnessed during the study.

It is important to note that none of the mentioned activities involved professionals from the institution. It was therefore observed that the institution does not provide play activities for the children. Multi-professional team work that involves occupational therapy and the children's health professionals would therefore support play and creative and instructive activity.

Moreover, technical training for professionals on the subject of play and multidisciplinary performance can enhance the positive consequences of play in hospital envi- 
ronments by providing health care and health education for these children and their families ${ }^{(15)}$.

Another fact is that most children used a play strategy that was mentioned when they were invited to participate in the study, which shows that play does actually occur and is considered important during the hospitalization period of children with cancer.

\section{The influence of play in the care process}

Play activities have several meanings for hospitalized children. Understanding these meanings should be part of the professional routine, considering that care involves knowledge and the ability to identify the care needs of patients ${ }^{(16)}$.

In this study, the children perceived play as being fun and as something that made them happy, as shown in the following statements:

[...] Some times I have nothing to do... then it's good to play, paint, draw, I like it [...] I like to see the pictures. If I see them, I feel happy. (Draculaura)

Yes, I go whenever I can. I think it's important for children, for their care... to have fun, too stalking about the playroom\}. (Mickey)

The main feelings observed in the children during play were joy and contentment ${ }^{(17)}$, as stated by the subjects of this study. Play reduces the tension and makes the environment more enjoyable. It is also recognized as a necessary therapeutic measure in paediatric care ${ }^{(15)}$.

Moreover, studies have already emphasized the relationship between emotions and immunity. Patients enjoying pleasant situations and stimulated to laugh show a slight increase in their defence system, and a boost in their well-being ${ }^{(18)}$. This is expressed in the following statements:

[...] It's fun, he plays with people, makes them happy when they are sad \{about the clown\}. [...] the clown plays with us and we get distracted....have fun, it's caring for us. (Spider-Man)

The aim of clowns who work at hospitals is to reduce the trauma of hospitalization by using laughter as a therapeutic measure in the care of children with cancer. The satisfaction of interacting with the clown stimulates laughter and benefits the organism and the patient's relationships with others ${ }^{(18)}$. Furthermore, as perceived in this study, clowns encourage children of the same room to talk to each other and jointly participate in the activities. The en- tertainment provided by clowns at the institution helped the children to relax and smile, and facilitated their interactions with others, which favours bonding and the well-being of all the subjects involved.

Another beneficial factor revealed in the statements is that play created a feeling of distraction.

Oh, I don't know... it's because the television helps me think about other things, so I get distracted, and I think that's care, it's good for me. The computer [...] is a distraction so I don't just watch TV all the time. (Mickey)

Because staying at the hospital can be boring, there's nothing to do... and when I watch, it's nice. (Draculaura)

Play can represent an escape from reality and make the hospital a more pleasant and controllable place for children ${ }^{(14,17)}$.

Play therefore provides a distraction and allows children to forget, for an instant, the suffering caused by their illness and by hospitalization. It also offers a chance for children to play some of the games they play at home, which improves their quality of life. As shown in a study conducted with a similar population, children maintain their involvement in the activities and seem to forget their illness and the reason for their hospitalization ${ }^{(17)}$, which was also identified in this study.

In addition, play can promote a relationship of trust, tranquillity and safety among the subjects involved, as shown below:

I feel good, it's fun [...] people coming to play with me with this game. (Julio)

Julio's statement reveals the importance of the relationship component during hospitalization. Some times, due to the treatment itself that reduces immunity, children stay in isolated rooms or rarely interact with the other children at the institution.

This often triggers feelings of loneliness in a foreign environment where there are only adults who are not always willing or do not have the spare time to play or talk to these children. Consequently, play emerges as a chance to promote approximation among the subjects during hospitalization.

Play can constitute a means of interaction through which the socialization of children is intensified ${ }^{(19)}$. Relationships with other people of a similar age are necessary for their development, so play becomes an effective way to enable well-being and interaction during hospitalization. Therefore, the children's statements revealed that play can be used to recreate, stimulate, socialize and provide a ther- 
apeutic function ${ }^{(3)}$. For this reason, health care professionals have the active role of recognizing the moments in which play can be used, and its purposes based on the individuality and needs of each child.

\section{口CONCLUSION}

According to findings of this study, the play activities reported by the hospitalized children with cancer involved watching television, using computers, games and toys, drawing, the playroom and the clown. These activities, according to the interviewed children, provide fun, feelings of joy, distractions and interaction with other people. Thus, they are considered essential in the process of care in that they favour well-being and reduce the discomfort of hospitalization.

The study also shows that health care professionals do not participate in these activities effectively or as a part of the care process. This finding should be further discussed and the reasons for this lack of participation should be the subject of further studies. Additional studies should also define strategies that enable these professionals to familiarize themselves with play instruments to improve the quality of care provided to children with cancer.

It should be noted that the results of this study can be the reflection of peculiarities of the hospital environment where the research was conducted and the personal experiences of hospitalized children in relation to cancer. It is therefore important to conduct new investigations at other institutions to better understand the conceptions of children in relation to play.

\section{DEFERENCES}

1. Lira ACM, Mate CH. Jogos e brincadeiras nas práticas pedagógicas na educação infantil: entre o dito e o escrito. Currículo sem Fronteiras. 2013;13(1):5-19.

2. Monteiro LS, Corrêa VAC. Reflexões sobre o brincar, a brinquedoteca e o processo de hospitalização. Rev Para Med. 2012;26(3):3 telas.

3. Jansen MF, Santos RM, Favero L. Benefícios da utilização do brinquedo durante o cuidado de enfermagem prestado à criança hospitalizada. Rev Gaúcha Enferm. 2010;31(2):247-53.
4. Cunha GL, Silva LF. Lúdico como recurso para o cuidado de enfermagem pediátrica na punção venosa. Rev RENE. 2012;13(5):1056-65.

5. Lima KYN. Processo de cuidar de crianças hospitalizadas com câncer [dissertação]. Natal (RN): Departamento de Enfermagem, Universidade Federal do Rio Grande do Norte; 2014.

6. Bardin L. Análise de conteúdo. Lisboa: Edições 70; 2011.

7. Luz J H, Martini JG. Compreendendo o significado de estar hospitalizado no cotidiano de crianças e adolescentes com doenças crônicas. Rev Bras Enferm. 2012;65(6):916-21.

8. Santos DC, Maranhão DG. 0 brincar como uma dimensão do cuidado de enfermagem à criança. Rev Enferm UNISA. 2012;13(1):27-32.

9. Avelar LFS, Teixeira LH. Jogos populares: pesquisa sociocultural e importância Iúdica para o desenvolvimento infantil. Cad Pesq. 2009;16(3):76-80.

10. Ellis SJ, Drew D, Wakefield CE, Saikal SL, Punch D, Cohn RJ. Results of a nurseled intervention: connecting pediatric cancer patients from the hospital to the school using videoconferencing technologies. J Pediatr Oncol Nurs. 2013;30(6):333-41.

11. Maia EBS, Ribeiro CA, Borba RIG. Compreendendo a sensibilização do enfermeiro para 0 uso do brinquedo terapêutico na prática assistencial à criança. Rev Esc Enferm USP. 2011;45(4):839-46.

12. Presidência da República (BR). Lei no 11.104, de 21 de março de 2005. Dispõe sobre a obrigatoriedade de instalação de brinquedotecas nas unidades de saúde que ofereçam atendimento pediátrico em regime de internação [internet]. Diário Oficial da União, Brasília, DF, 2005 [accessed on 2014 maio 01]. Available at: http:// http://www.planalto.gov.br/ccivil_03/_At02004-2006/2005/Lei/ L11104.htm

13. Oliveira IM, Gebara A. Interação, afeto e construção de sentidos entre crianças na brinquedoteca. Educ Pesqui. 2010;36(1):373-87.

14. Lima RAG, Azevedo EF, Nascimento LC, Rocha SMM. A arte do teatro clown no cuidado a crianças hospitalizadas. Rev Esc Enferm USP. 2009;49(1):186-93.

15. Oliveira LDB, Gabarra LM, Marcon C, Silva JLC, Macchiaverni J. A brinquedoteca hospitalar como fator de promoção no desenvolvimento infantil: relato de experiência. Rev Bras Crescimento Desenvolv Hum. 2009;19(2):306-12

16. Waldow VR. Cuidar de sí, cuidar del otro, cuidar del todo: implicaciones para la salud y enfermería. Enfermería: Cuidados Humanizados. 2013;2(1):53-6.

17. Borges EP, Nascimento MDSB, Silva SMM. Benefícios das atividades lúdicas na recuperação de crianças com câncer. Bol Acad Paul Psicol. 2008; 18(2):211-21.

18. Abreu GRF. A terapia do (bom)humor nos processos de cuidado em saúde. Rev Baiana Enferm. 2011;25(1):69-74.

19. Melo LL, Valle ERM. A brinquedoteca como possibilidade para desvelar o cotidiano da criança com câncer em tratamento ambulatorial. Rev Esc Enferm USP. 2010;44(2):517-25.

\section{Author's address:}

Kálya Yasmine Nunes de Lima

Rua Sapotizeiro, 1946, Potengi

59120-410 Natal - RN

E-mail: lima.yasmine@yahoo.com.br
Received: 12.11.2014

Approved: 19.03.2015 